Published in final edited form as:

Bioconjug Chem. 2018 September 19; 29(9): 3161-3173. doi:10.1021/acs.bioconjchem.8b00484.

\title{
Photoactivable Glycolipid Antigens Generate Stable Conjugates with CD1d for Invariant Natural Killer T Cell Activation
}

\author{
Natacha Veerapen ${ }^{\dagger, \#}$, Shalu Sharma Kharkwal ${ }^{\S}$, , Peter Jervis ${ }^{\dagger}$, Veemal Bhowruth ${ }^{\dagger}$, \\ Amareeta K. Besra ${ }^{\dagger}$, Simon J. North ${ }^{\Uparrow}$, Stuart M. Haslam $\rrbracket$, Anne Dellף, Judith Hobrath ${ }^{\square}$, \\ Padraic J. Quaid ${ }^{\dagger}$, Patrick J. Moynihan ${ }^{\dagger}$, Liam R. Cox ${ }^{\ddagger}$, Himanshu Kharkwal", Maurice \\ Zauderer $^{\nabla}$, Gurdyal S. Besra ${ }^{*}$, , and Steven A. Porcelli ${ }^{*}, \S, \perp$ \\ †School of Biosciences, University of Birmingham, Edgbaston, Birmingham, B15 2TT, United \\ Kingdom \\ ¥School of Chemistry, University of Birmingham, Edgbaston, Birmingham, B15 2TT, United \\ Kingdom
}

§Department of Microbiology and Immunology, Albert Einstein College of Medicine, Bronx, New York 10461, United States

"Department of Developmental and Molecular Biology, Albert Einstein College of Medicine, Bronx, New York 10461, United States

${ }^{\perp}$ Department of Medicine, Albert Einstein College of Medicine, Bronx, New York 10461, United States

IDepartment of Life Sciences, Faculty of Natural Sciences, Imperial College London, South Kensington Campus, London, SW7 2AZ, United Kingdom

$\square$ Drug Discovery Unit, College of Life Sciences, University of Dundee, Dow Street, Dundee, DD1 $5 \mathrm{EH}$, Scotland, United Kingdom

$\checkmark$ Vaccinex Inc., 1895 Mount Hope Avenue, Rochester, New York 14620, United States

\section{Abstract}

\begin{abstract}
Activation of invariant natural killer T lymphocytes (iNKT cells) by $a$-galactosylceramide ( $a$-GC) elicits a range of pro-inflammatory or anti-inflammatory immune responses. We report the synthesis and characterization of a series of $a$-GC analogues with acyl chains of varying length and a terminal benzophenone. These bound efficiently to the glycolipid antigen presenting protein CD1d, and upon photoactivation formed stable CD1d-glycolipid covalent conjugates. Conjugates of benzophenone $a$-GCs with soluble or cell-bound CD1d proteins retained potent iNKT cell
\end{abstract}

\footnotetext{
*Corresponding Authors : steven.porcelli@einstein.yu.edu. Phone: 718-430-3228. Fax: 718-430-8711.; g.besra@bham.ac.uk. Phone: +00 44121415 8125. Fax: +00 441214145925.

\#Natacha Veerapen and Shalu Sharma Kharkwal contributed equally to this manuscript.

Supporting Information

The Supporting Information is available free of charge on the ACS Publications website at DOI: 10.1021/acs.bioconjchem.8b00484. Synthetic Schemes; General procedures for chemical analyses; Experimental details for the synthesis of compounds; NMR spectra of selected compounds; Experimental Methods; Supporting Figures and Tables (PDF)

The authors declare the following competing financial interest(s): Dr. Maurice Zauderer is the founder and CEO of Vaccinex Inc., that has invested interest in developing NKT cell-based Immunotherapies. Dr. Steven A Porcelli is a paid consultant at Vaccinex Inc.
} 
activating properties, with biologic effects that were modulated by acyl chain length and the resulting affinities of conjugates for iNKT cell antigen receptors. Analysis by mass spectrometry identified a unique covalent attachment site for the glycolipid ligands in the hydrophobic ligand binding pocket of CD1d. The creation of covalent conjugates of CD1d with $a$-GC provides a new tool for probing the biology of glycolipid antigen presentation, as well as opportunities for developing effective immunotherapeutics.

\section{Graphical Abstract}
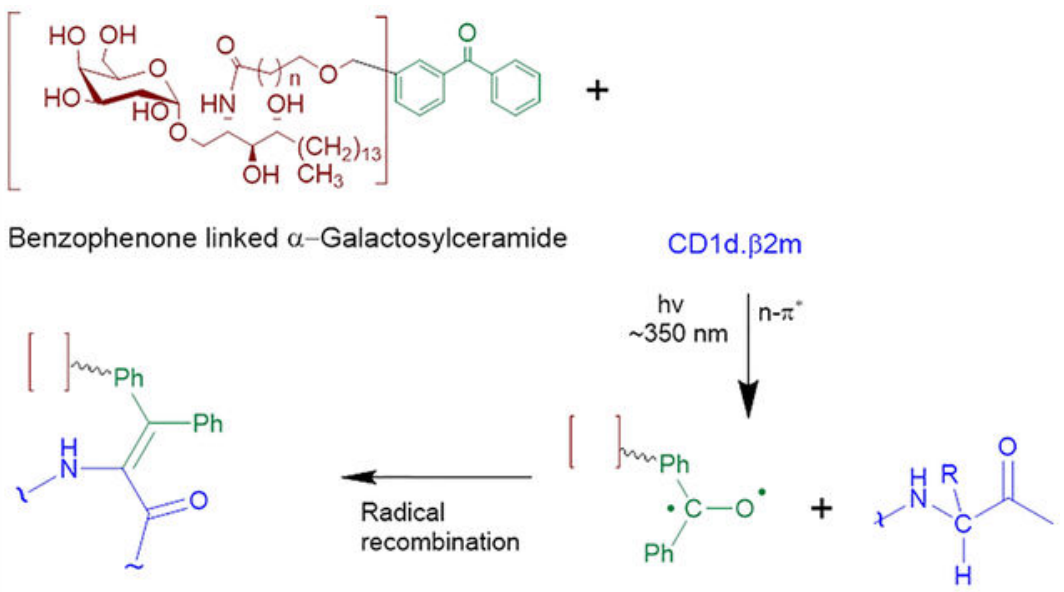

Covalent CD1d:BPGC

Conjugate

\section{INTRODUCTION}

Invariant Natural Killer T (iNKT) cells are a prominent subset of unconventional $\mathrm{T}$ cells that bridge innate and adaptive immunity to contribute to a wide range of immune responses. ${ }^{1}$ They recognize and respond to glycolipid antigens presented by CD1d, a membrane protein specialized for binding and presentation of lipid antigens. ${ }^{2}$ The most extensively studied CD1d-presented glycolipid antigens are synthetic forms of $a$-galactosylceramide ( $a$-GC), which potently stimulate iNKT cell proliferation, expansion, and cytokine secretion. ${ }^{3}$ In mice, various structural analogues of $a$-GC have shown impressive anticancer effects, ${ }^{4}$ as well as a broad range of activities in models of infection, vaccination, autoimmunity, and inflammatory diseases. ${ }^{5}$ Thus, there has been increasing interest in using $a$-GC analogues to develop new approaches to vaccination or immunotherapy. ${ }^{4 c, 6}$

Despite the potent immune activating properties of $a$-GC and the conservation of a CD1drestricted iNKT cell subset in humans, there has been limited success so far in translating iNKT cell-based approaches into clinical applications. This may reflect problems with systemic delivery of glycolipid agonists, which leads to their uptake and presentation by a wide range of cell types and the stimulation of unpredictable or antagonistic immune responses. ${ }^{6 a, 7}$

Several approaches to overcoming these problems have been developed that involve delivery of $a$-GC by antigen presenting cells (APCs) or soluble recombinant CD1d proteins loaded 
ex vivo with the glycolipid. ${ }^{8}$ These approaches have shown potential to stimulate more effective antitumor responses compared to injections of free glycolipids in mouse models, as well as promising preliminary results in preclinical and clinical studies. ${ }^{4 c, 6 a, 8 c, d, 9}$ Also of note is the apparent ability of these methods to induce substantial iNKT cell activation while triggering less of the long-term unresponsiveness (anergy) or depletion of iNKT cells that has been a problem with injections of free glycolipids. ${ }^{10}$

However, a potential limitation is presented by the readily reversible binding of glycolipid ligands to $\mathrm{CD} 1 \mathrm{~d}$, which is mediated by noncovalent hydrophobic and hydrogen bonding interactions. ${ }^{2}$ Rapid dissociation has been reported to result in half-lives for $a \mathrm{GC}-\mathrm{CD} 1 \mathrm{~d}$ complexes in some in vitro studies as short as a few minutes or less, which may be further reduced in vivo by the presence of lipid exchange and binding proteins. ${ }^{11}$ The relatively short half-life and instability of such complexes limits the duration and potency of their desirable biologic effects, and the release of free glycolipids in vivo may contribute to unwanted effects such as iNKT cell anergy or toxicities including liver damage or sensitization to endotoxic shock. ${ }^{12}$ Thus, the relative instability of $a \mathrm{GC}-\mathrm{CD} 1 \mathrm{~d}$ complexes remains a suboptimal feature in approaches that involve ex vivo loading of cells or CD1d proteins with glycolipids, and can compromise the efficacy and precision of such controlled delivery methods.

In the current study, we have developed an approach to circumvent the problem of glycolipid dissociation from CD1d by the use of photoactivatable forms of $a$-GC to create covalently stabilized and highly active $a \mathrm{GC}-\mathrm{CD} 1 \mathrm{~d}$ conjugates. A series of analogues of $a$-GC containing a benzophenone group at the terminus of their $\mathrm{N}$-acyl chains was synthesized and optimized for iNKT cell stimulating activity. Controlled exposure to UV irradiation generated stable covalent conjugates of these glycolipids with CD1d, and these retained their ability to potently stimulate iNKT cells in vitro and in vivo in mice. Specific immunologic properties such as cytokine production could be modulated by variations in the size of the aliphatic chain bearing the benzophenone group, which was correlated with the affinity of the conjugates for the antigen receptors of iNKT cells. Mass spectrometry identified a unique site for covalent bond formation in the CD1d protein, enabling detailed modeling of the structure of the stable conjugates. The development of controlled covalent bond formation for stabilization of $a \mathrm{GC}-\mathrm{CD} 1 \mathrm{~d}$ conjugates provides a new tool for the study of glycolipid antigen presentation, and also forms the basis for improving immunotherapies based on the targeted delivery of iNKT cell activators.

\section{RESULTS}

\section{Synthesis of BPGCs.}

Extensive previous work has shown that many modifications of the fatty acyl chain of $a$-GC can be tolerated without disruption of glycolipid binding to CD1d or loss of iNKT cell stimulating activity, ${ }^{3}$ consistent with the large volume of the hydrophobic ligand binding site of CD1d. ${ }^{2,13}$ Thus, we developed a synthetic strategy for introduction of a photoactivatable moiety on the acyl chain terminus of $a$-GC to enable the controlled formation of a covalent bond between the glycolipid and the CD1d protein (Figure 1). The benzophenone group was chosen as it can be activated by UV irradiation to give the corresponding benzhydril 
biradical, which we postulated would react with a proximal C-H bond present in the CD1d protein to form a permanent covalent bond. A group of benzophenone-containing derivatives of $a$-GC (BPGCs) bearing acyl chains of various lengths (compounds 9-15) were synthesized to determine which would optimally associate with CD1d and effectively activate iNKT cells. Based on the resemblance of benzophenone to a $\mathrm{C} 10$ isoprene unit, we synthesized a range of BPGCs which mimic $N$-acyl chain lengths from C16 (C6:BP (9)) to $\mathrm{C} 26$ (C16:BP (15)), thus spanning the range found in most highly active $a$-GC analogues. ${ }^{3}$ These compounds were readily prepared via acylation of the parent compound $\mathbf{1}$ with carboxylic acids (2-8), following their conversion to the corresponding acid chlorides using oxalyl chloride. Ensuing acylation of the amine $\mathbf{1}$ in a 1:1 mixture of THF and saturated sodium acetate solution afforded the benzophenone-derivatized glycosphingolipids (BPGCs) 9-15 (Figure 1).

\section{Stimulation of iNKT Cells by BPGC Analogs.}

A variety of in vitro biological assays were performed to assess the iNKT cell activating properties of the BPGCs upon presentation by CD1d, and to determine the effect of the varying acyl chain lengths and the presence of a bulky terminal benzophenone group on their biologic activities. A standard assay using coculture of mouse bone marrow-derived dendritic cells (BMDCs) and a murine iNKT cell hybridoma was used to assess the activity and relative potencies of BPGCs (Figure 2a). ${ }^{15}$ This showed significant iNKT cell stimulating activity for all BPGCs tested, with a substantial impact of the length of fatty acyl chain. Optimal iNKT stimulation in the mouse cell culture system was achieved with 13, which along with several other BPGCs was significantly more potent than the standard $a$ GC (C26:0), which is generally considered a highly potent iNKT cell activator both in vitro and in vivo. ${ }^{4 a, 15}$ A similar in vitro analysis was carried out using a canonical human iNKT cell clone cocultured with HeLa cells transfected to express human CD1d (Figure 2b). ${ }^{16}$ This also revealed strong activity of BPGCs as measured by IFN- $\gamma$ secretion, which was similar to or greater than that stimulated by C26:0. As for the mouse culture system, compounds $\mathbf{1 2}$ and $\mathbf{1 3}$ showed the greatest potency in this assay, although the length of the fatty acyl tail had much less apparent impact in the human system.

To directly assess activity in vivo, we analyzed serum cytokine levels following intravenous injection of selected BPGCs. For this analysis, we tested $\mathbf{9}$ which was a relatively weak activator of murine iNKT cells in vitro, and $\mathbf{1 3}$ and $\mathbf{1 5}$ which were more potent than C26:0 in both mouse and human cell culture assays. Mice were injected with $4 \mathrm{nmol}$ of each glycolipid and bled after 2,10 , and $24 \mathrm{~h}$ to quantitate serum IFN- $\gamma$ and IL-4, as previously described. ${ }^{15}$ Significant levels above baseline for serum IL-4 were detected with $\mathbf{1 3}$ and $\mathbf{1 5}$ at $2 \mathrm{~h}$, which declined to undetectable levels by $10 \mathrm{~h}$ (Figure 2c). The IL-4 levels were several-fold higher for $\mathbf{1 3}$ and $\mathbf{1 5}$ compared to C26:0, indicating a rapid and powerful activation of iNKT cells. Consistent with this, IFN- $\gamma$ levels showed a sustained rise with $\mathbf{1 3}$ and 15 with a peak at $10 \mathrm{~h}$ that closely resembled the response to C26:0, while 9 did not stimulate detectable levels above background for either cytokine tested. Thus, BPGCs retained their iNKT cell activating properties in vivo, and the potencies of different analogues varied depending on the length of their acyl chains. 


\section{Formation of Covalent CD1d-Glycolipid Conjugates by Photoactivation.}

The known photochemical properties of benzophenones predicted that loading of BPGCs into CD1d proteins followed by exposure to UV irradiation should form covalently stabilized protein-glycolipid conjugates. We validated this initially using a 3-fold molar excess of ${ }^{14} \mathrm{C}$-labeled analogue of $\mathbf{1 3}$, compound $\mathbf{2 6}$ (Scheme 2, SI) to load soluble recombinant $\mathrm{mCD} 1 \mathrm{~d}$ protein. Aliquots of the loaded protein were then exposed to a $365 \mathrm{~nm}$ UV lamp for times ranging from 0 to $90 \mathrm{~min}$, followed by denaturation $\left(1 \% \mathrm{SDS}\right.$ at $100{ }^{\circ} \mathrm{C}$ for $5 \mathrm{~min}$ ) and separation by SDS-PAGE. Staining of the gel with Coomassie blue revealed intact protein in all samples, which ran at the predicted size of $\sim 57 \mathrm{kDa}$ for monomeric soluble CD1d (Figure 3a). Autoradiography of the same gel revealed the presence of the ${ }^{14} \mathrm{C}$ label co-migrating with CD1d protein in the samples exposed to UV light, but not in the unexposed sample (Figure 3b). Maximum association of radiolabel, indicating the formation of stable protein-glycolipid conjugates that were resistant to denaturation, was achieved following 30 to $60 \mathrm{~min}$ of UV exposure, corresponding to a delivered dose range of 400-600 mJoules $/ \mathrm{cm}^{2}$. Radiometric analysis showed that approximately $70 \%$ of CD1d molecules were conjugated to ${ }^{14} \mathrm{C}$ labeled 26 after 60 min of UV exposure (SI Figure S1).

Further analysis of conjugate formation was carried out in studies using compound $\mathbf{2 5}$ (synthesis described in SI), an analogue of $\mathbf{1 3}$ carrying an azido group at the $\mathbf{6}^{\prime}$-position of the saccharide headgroup (Figure 3c). Complexes formed between this glycolipid and soluble mCD1d were either irradiated with UV $\lambda_{365}$ or not, and then incubated with fluorescent DBCO-TAMRA, which reacts with the azido group of the glycolipid. ${ }^{17}$ The samples were then denatured and analyzed by SDS-PAGE. While gels stained with Coomassie blue showed similar CD1d protein in both samples (migrating at $\sim 78 \mathrm{kDa}$, consistent with the mCD1d fusion protein used for this experiment; see SI Methods for details), only the sample exposed to UV had a fluorescent signal co-migrating with CD1d (Figure 3d). This confirmed the formation of stable conjugates following photoactivation of the benzophenone moiety in CD1d-glycolipid complexes. In addition, the ability of the DBCO-TAMRA reagent to couple to the azido group was consistent with correct orientation of the $\mathbf{1 3}$ in the CD1d lipid binding groove, with the carbohydrate headgroup exposed and accessible at the surface of the protein.

To confirm the correct conformation and stability of covalent mCD1d-BPGC conjugates, we tested reactivity with mAb L363, which binds specifically to CD1d loaded with $a$-GC in a manner that closely mimics the TCRs of iNKT cells. ${ }^{18}$ Plate immobilized mCD1d proteins were loaded with BPGCs, then either UV irradiated or not and tested for binding of L363. This showed binding to levels comparable to that with C26:0 loaded mCD1d (Figure 3e). Furthermore, after repeated washing with buffer containing mild detergent to remove reversibly bound glycolipids, we observed a significant loss of L363 binding in samples without UV irradiation. In contrast, UV exposed samples loaded with BPGCs showed no significant loss of L363 binding, indicating covalent bond formation. As expected, L363 binding to mCD1d loaded with C26:0 was reversible under these conditions with or without UV exposure. To further characterize the biologic activity of these complexes or conjugates, we also assessed their ability to stimulate iNKT cell activation in mouse splenocytes (Figure 3f). The UV treated stable conjugates retained their iNKT cell stimulating activity at levels 
comparable to noncovalent complexes, indicating that UV exposure and covalent bond formation did not adversely alter TCR recognition. Analysis of all seven BPGCs in this assay showed an influence of the acyl chain spacer length on potency of stimulation, with $\mathbf{1 3}$ generally showing the strongest stimulation.

In addition to the analyses of loading and photo-cross-linking to purified recombinant CD1d proteins, we also assessed the formation of stabilized mCD1d-glycolipid conjugates on intact CD1d-expressing antigen presenting cells. We used the murine immortalized dendritic cell line JAWS II for this, since it expresses mCD1d and is capable of glycolipid antigen presentation. ${ }^{19}$ Incubation of these cells with either C26:0 or $\mathbf{1 3}$ generated strong surface staining with mAb L363, which for both glycolipids was greatly reduced following incubation for 1 day in the absence of the glycolipids. In contrast, exposure of the cells to UV irradiation following culture with the $\mathbf{1 3}$ eliminated any loss of L363 staining with subsequent culture, whereas UV irradiation of C26:0 loaded cells did not prevent decay of L363 binding under the same conditions (Figure 3g). This strongly suggested that stabilized covalent CD1d-glycolipid conjugates were produced by UV photoactivation of BPGCs in living cells. This was further evaluated by testing the ability of JAWS II cells loaded with $\mathbf{1 3}$ and UV treated to stimulate iNKT cell responses in vivo following adoptive transfer of the cells into mice (Figure $3 \mathrm{~h}$ ). We detected strong serum cytokine responses in mice receiving cells bearing the putative covalently stabilized conjugates, and a reduced level of IL-4 relative to IFN- $\gamma$ was observed when compared to injection of cells presenting noncovalent complexes (i.e., JAWS II cells without UV photoactivation or loaded with C26:0).

\section{Impact of Conjugation on TCR Affinity and Biologic Activity in vivo.}

By eliminating dissociation of glycolipid binding to CD1d, we anticipated that conjugation should increase the overall affinity of cognate interactions with iNKT cell TCRs. To assess this, fluorescent tetramers of soluble mCD1d loaded with C26:0 or BPGCs were prepared with and without covalent cross-linking. Binding avidities of tetramers to the TCRs of mouse iNKT cell hybridoma line DN3A4-1.2 were quantified by measuring equilibrium binding to the cells over a range of concentrations, as previously described. ${ }^{15}$ Extrapolation of the equilibrium dissociation constant $\left(K_{\mathrm{D}}\right)$ values showed maximum avidities for $\mathrm{C} 26: 0$ and 15 loaded noncovalent complexes, while avidities declined progressively for BPGCs with shorter acyl tail spacers (Figure 4a). This trend was not evident with the binding of covalent conjugate tetramers, as the conjugates with shorter acyl chain variants of BPGCs showed enhanced and more uniform avidities. These results indicated that dissociation of the glycolipids with shorter acyl tails had a major impact in TCR avidity, which was reversed by covalent stabilization of the glycolipid-protein interaction. One apparent exception was the 9 conjugate, which showed a distinctly lower TCR avidity than the other conjugates tested despite covalent stabilization.

We next assessed the in vivo activities of soluble mCD1d-BPGC complexes and conjugates using three different BPGCs that varied in their affinities for iNKT cell TCRs. After a single i.v. injection of mCD1d complexes or conjugates loaded with $\mathbf{9}, \mathbf{1 3}$, or 15 (30 $\mu \mathrm{g}$ of mCD1d protein containing $\sim 0.4 \mathrm{nmol}$ of each glycolipid), serum levels of IL-2, TNF- $a$, IL-4, and IFN- $\gamma$ were determined at 2,10 , and $24 \mathrm{~h}$ after administration (Figure $4 \mathrm{~b}$, and SI Figure S2). 
Injection of C26:0 as a free glycolipid was used as a standard which is known to activate iNKT cell-dependent release of various cytokines, such as IL-2, TNF- $a$, and IL-4 which peak in serum at approximately $2 \mathrm{~h}$, and IFN- $\gamma$ which peaks at $10-12 \mathrm{~h}$ after the injection. ${ }^{20}$ The administration of conjugates formed with $\mathbf{1 3}$ or $\mathbf{1 5}$ activated secretion of all four cytokines, including levels of IL-2, TNF- $a$, and IL- 4 at $2 \mathrm{~h}$ and IFN- $\gamma$ at $10 \mathrm{~h}$, that equaled or exceeded those stimulated by free $\mathrm{C} 26: 0$. Noncovalent complexes gave similar stimulation as conjugates at $2 \mathrm{~h}$, but the level of IFN- $\gamma$ at $10 \mathrm{~h}$ was significantly higher with conjugates for 13, and also for conjugates with 9 which did not stimulate any detectable serum cytokines at $2 \mathrm{~h}$. These findings confirmed the iNKT cell activating properties of soluble complexes and conjugates in vivo, and also were consistent with the ability of covalent conjugation to stabilize the shorter $\mathbf{9}$ and $\mathbf{1 3}$ glycolipids, extending the duration of their bioactivity. In addition, covalently stabilized $\mathbf{9}$ conjugates showed a remarkable skewing of the cytokine response such that only IFN $-\gamma$ was detected among the cytokines measured.

\section{Analysis of Conjugation Site by Peptide Mapping.}

Peptide mapping analyses of samples of native mCD1d and mCD1d conjugates with $\mathbf{9}$ and 13 were performed to identify possible sites of conjugation. Samples with or without enzymatic deglycosylation were digested with trypsin, or with trypsin plus chymotrypsin. Digested samples were analyzed by online nanoliquid chromatography-electrospray tandem mass spectrometry (nano-LC-ES-MS ${ }^{\mathrm{E}}$ ) (SI Figure S4). For native mCD1d samples, peptides covering the entirety of the glycolipid binding domains were consistently mapped with a high degree of confidence for all but three residues (R156, M218, and M219) of the putative binding site. Both the $\mathbf{9}$ and $\mathbf{1 3}$ conjugated samples produced very similar data to that of the native $\mathrm{mCD} 1 \mathrm{~d}$, with the notable exception that ions covering the unmodified region ${ }_{255} \mathrm{YVVR}_{258}$ were not observed (Figure 5a, and SI Tables S1-S3). Instead, molecular ions consistent with the presence of a $\mathbf{1 3}$ or $\mathbf{9}$ modification were detected (SI Figures S4 and S5), and fragmentation of these modified peptides produced signals corresponding to both the $\mathrm{N}$ terminal tyrosine and the C-terminal arginine, as well as $\mathrm{y}^{\prime \prime}$ - and b-ions consistent with modified VVR and YVV (Figure 5b). Although definitive evidence for covalent modification of a specific residue was not obtained, these data strongly supported the site of conjugation to be in the region ${ }_{255} \mathrm{YVVR}_{258}$, with one or both valine residues at the base of the $\mathrm{F}^{\prime}$ pocket of $\mathrm{mCD} 1 \mathrm{~d}$ being directly involved in the formation of potential bioconjugation products (Figure 5C and SI Figure S6).

\section{Modeling BPGC Analogue Binding Modes.}

To confirm the feasibility of the putative conjugation site identified in mCD1d, the binding modes of 9 and 13 were modeled into the published crystal structure of the ternary complex of CD1d with $a$-GC C26:0 and the Va14-V $\beta 8.2$ iNKT cell TCR (PDB entry code 3HE6) (Figure 5c and Figure 6). Briefly, compound 13 was docked without its benzophenone group, which was deleted prior to docking. The binding of the modified benzophenone group (i.e., diphenylmethanol, formed by the benzophenone group after conjugation) was predicted in a separate docking run considering that the flexible linker in the BPGC analogues would only minimally restrain possible binding conformations of the end group. The most favorable docking pose showed excellent shape complementarity and nonpolar 
contacts in the binding site while linked covalently to the V257 side chain in the $\mathrm{F}^{\prime}$ pocket. The diphenylmethanol pose and the sugar moiety of $\mathbf{1 3}$ docked without the benzophenone end group were then connected by predicting an optimal conformation for the flexible linker between them through docking the linker segment (with constraints). Models of the full 9 and $\mathbf{1 3}$ structures were generated through splicing in the appropriate linkers of the two BPGC analogues, and were then refined using Prime complex structure refinement in Schrödinger software (Figure 6).

The final refined structures of $\mathbf{9}$ and $\mathbf{1 3}$ glycolipids after docking showed similar binding modes except for the linker region, as expected (Figure 6, inset). Compared to the corresponding sugar moiety of $a$-GC C26:0 in the crystal structure, the $a$-galactopyranosyl group in BPGC analogues was positioned closer to the TCR and slightly shifted (Figure 6a). The lipid chains occupying the $\mathrm{A}^{\prime}$ and $\mathrm{F}^{\prime}$ pockets in the models with bound BPGCs were switched compared to the orientation of $a$-GC C26:0 in the crystal structure. Thus, the acyl chain of the covalently bound $\mathbf{9}$ and $\mathbf{1 3}$ was positioned in the $\mathrm{F}^{\prime}$ pocket of mCD1d, rather than in the $\mathrm{A}^{\prime}$ pocket as in the case of the noncovalently bound $a$-GC C26:0 (Figure 6a and b). This binding orientation allowed reorientation of the TCR $a$ R95 side chain (R95a) to form a favorable stacking interaction between the guanidinium of the arginine and the amide of the ligand, as well as a number of other stabilizing interactions (Figure 6c). The acyl chains of $\mathbf{9}$ and $\mathbf{1 3}$ adopted quite similar orientations in the two BPGC models in spite of their different lengths, linking the diphenylmethanol moiety covalently bound to the side chain of V257 in a mainly nonpolar pocket (Figure 6d).

\section{DISCUSSION}

In this study we synthesized a series of benzophenone-modified glycolipids that can be covalently cross-linked to soluble as well as surface expressed CD1d to generate highly stable conjugates that activate iNKT cells in vitro and in vivo. By appending a photoactivatable benzophenone group to the end of the amide linked acyl chain of $a$-GC, we generated a family of BPGCs with varying aliphatic spacer lengths. Screening for biologic activity using a variety of assays for iNKT cell stimulation showed that all of these BPGCs could be presented by CD1d, with most experiments showing 13 to be optimal for iNKT cell stimulation. Using relatively brief and low energy UV irradiation, all of the BPGCs could be activated to form stable conjugates with purified CD1d proteins. In addition, UV photoactivation could be shown to stabilize BPGC interactions with CD1d expressed in living cells. By multiple criteria, UV induced covalent conjugates of BPGCs retained their interactions with iNKT cell TCRs, and conjugates in either soluble, surface bound, or cell associated forms possessed the ability to activate cytokine secretion by iNKT cells.

Our primary goal in developing BPGCs was to use conjugate formation with CD1d as a method for improving delivery of iNKT cell activators as potential agents for immunotherapy. Particularly in the case of cancer immunotherapy, many studies in mouse models have highlighted the potential for iNKT cell activators to deliver striking anticancer effects. ${ }^{4 \mathrm{c}}$ However, administration of $\boldsymbol{a}$-GC as a free glycolipid has the potential for dose limiting toxicity, and also leads to the rapid development of a long-lived hyporesponsive state (anergy) that interferes with repeated treatments. ${ }^{10,21}$ Most likely, these issues 
contribute to the limited efficacy of free $a$-GC injections observed so far in early phase clinical trials for cancer in humans. ${ }^{9,22}$ Approaches to more precisely deliver $a$-GC to overcome these problems have been developed, including the administration of ex vivo glycolipid loaded antigen presenting cells or targeted soluble recombinant CD1d proteins. $4 \mathrm{c}, 8 \mathrm{a}, \mathrm{c}, \mathrm{d}$ These approaches have shown improved outcomes in animal models, as well as in limited clinical studies in cancer patients. ${ }^{4 \mathrm{c}, 6 \mathrm{~b}, 23}$ However, the ability of $a$-GC to dissociate from these delivery vehicles after in vivo injection remains a suboptimal feature. The use of BPGCs to covalently lock the glycolipid onto CD1d in an active configuration, as shown in the current study, represents a method for improving these delivery methods, and achieving more focused and effective immunotherapy without the limitations or toxic effects of systemic $a$-GC injections.

Detailed analysis of the effects of variation in the length of the acyl chain spacer in the BPGCs revealed some interesting and potentially important findings. First, we noted that the $\mathbf{9}$ and $\mathbf{1 0}$ compounds had very low TCR affinity and low stimulatory activity when not covalently linked to CD1d (Figures $3 \mathrm{f}$ and $4 \mathrm{a}$ ), presumably because of their rapid dissociation. However, with conjugate formation these glycolipids showed improved affinity and enhanced iNKT cell stimulation. This suggests that the BPGCs with shorter acyl chains, even if released by some mechanism after conjugation, should be less likely to induce unwanted effects such as iNKT cell anergy or systemic toxicity. Another notable finding was that 9 , which even after conjugation continued to show a lower TCR affinity than the other BPGCs, also gave a remarkably biased cytokine response (i.e., significant IFN- $\gamma$ levels with no detectable IL-4 or other cytokines) when injected in the form of a conjugate with soluble CD1d protein (Figure 4b). This type of "Th1-biased" cytokine response has been repeatedly associated in previous studies with analogues of $a$-GC that provide superior antitumor responses in mouse models. ${ }^{24}$ Thus, through alterations in the length of the acyl chain spacer, it should be possible to tune the responses to BPGC conjugates in terms of affinity and biologic response to optimize desired therapeutic outcomes.

Our mapping of the site of covalent bond formation in $\mathbf{9}$ and $\mathbf{1 3}$ conjugates yielded the surprising finding of a single major conjugation site for both glycolipids. Another surprising aspect of this result was that the specific region of CD1d that was implicated was located near the base of the $\mathrm{F}^{\prime}$ pocket, which in all CD1d-glycolipid complexes resolved by X-ray crystallography would be predicted to be in greater proximity to the sphingoid base than the acyl tail of the glycolipid (Figure 5c). ${ }^{2}$ However, this apparent switch in the orientation of the two lipid tails of the glycolipid can be readily accommodated in energetically favorable poses of the glycolipid in molecular models (Figure 6). Thus, our findings suggest the possibility of greater flexibility in the lipid binding process of CD1d, which has only been occasionally hinted at in atomic level structure studies. ${ }^{25}$ Further structural analyses of CD1d-BPGC conjugates should enable new types of analyses to expand our understanding of the unique process of glycolipid antigen presentation, as well as opportunities for improving immuno-therapies that target iNKT cells. 


\section{EXPERIMENTAL METHODS}

\section{Synthesis and Compound Characterization.}

Full experimental details of the synthesis and characterization of all compounds used in this study are provided in the Supporting Information.

Mice.

Female C57BL/6J (B6) mice 6-8 weeks old were obtained from Jackson Laboratories or Taconic and maintained in pathogen-free conditions. All experiments requiring mice were conducted in compliance with institutional guidelines and under an authorization delivered by the Institute of Animal Use and Biosafety Committee at Albert Einstein College of Medicine.

\section{Cell Lines, Clones, and Hybridomas.}

HeLa cells transfected with human CD1d (HeLa.hCD1d) were cultured in DMEM supplemented with $10 \%$ FBS, and JAWS II cells were cultured in $a$-MEM supplemented with $10 \% \mathrm{FBS}$ and $20 \mathrm{ng} / \mathrm{mL}$ murine GM-CSF. Mouse splenocytes were maintained in RPMI with 10\% FBS. BMDCs were prepared as described earlier and cultured in RPMI supplemented with 10\% FBS. Mouse iNKT hybridoma DN3A4-1.2 was maintained in complete RPMI medium containing 10\% decomplemented serum. ${ }^{26}$ Human iNKT clonal HDE3 was clonally expanded by stimulation with PHA-P in the presence of recombinant human IL-2 at $250 \mathrm{IU} / \mathrm{mL}$, recombinant human IL-7 at $10 \mathrm{ng} / \mathrm{mL}$ and allogeneic PBMCs (irradiated at $5000 \mathrm{rad}$ ), and cultures were fed by addition of fresh medium containing IL-7 and IL-2 every $2-3$ days. ${ }^{8 \mathrm{~d}, 15}$

\section{Recombinant CD1d Proteins and Monoclonal Anti-body L363.}

Single chain $\beta 2 \mathrm{~m}$-mouse CD1d-hexahistidine (MW $57 \mathrm{kDa}$ ) and human CD1d- $\beta 2 \mathrm{~m}$ hexahistidine were purified from $\mathrm{CHO}$ cells stably transfected with respective genes. ${ }^{27,15}$ Single chain $\mathrm{mCD} 1 \mathrm{~d}-\beta 2 \mathrm{~m}$ with a C-terminal single chain immunoglobulin Fv fusion (mCD1d- $\beta 2 \mathrm{~m}-\mathrm{ScFv}, \mathrm{MW} \sim 78 \mathrm{kDa}$ ) was produced in transiently transfected HEK cells and purified as previously described. ${ }^{8 c, d}$ The $\mathrm{ScFv}$ moieties of these proteins were specific for the human tumor associated antigens CEA or $\mathrm{C} 35$, although their specific binding properties were not relevant to experiments in the current study.

To determine the affinity of mCD1d-BPGC tetramers for iNKT-cell TCRs, $1 \times 10^{4}$ DN3A4-1.2 cells were stained with a range of concentrations of tetramers loaded with the different glycolipids to form complexes. Soluble mCD1d proteins were prepared and biotinylated following published methods with minor modifications. ${ }^{28}$ Glycolipids were prepared and loaded onto soluble mCD1d as described in the following section. In some cases, the loaded mCD1d complexes were converted to covalent conjugates by exposure to UV irradiation for $60 \mathrm{~min}$ in solution $\left(400 \mathrm{mJoules} / \mathrm{cm}^{2}\right.$ ). Formation of tetramers, equilibrium binding of tetramers to NKT cells, and measurement of binding by flow cytometry has been previously described in detail. ${ }^{15}$ 
Monoclonal antibody L363, specific for mCD1d with bound $a$-GC C26:0 and other related forms of $a$-GC, has been previously described ${ }^{15,18,29}$ The antibody was purified from supernatants of the cultured hybridoma line, and was biotinylated using sulfo-NHS biotinylation kit or fluorescently tagged with Alexa Fluor 647 (Alexa 647 labeling kit, Thermo Fisher). Binding of fluorescently labeled L363 to cells was determined by flow cytometry using an LSR II cytometer (BD Biosciences) and FlowJo software. ${ }^{15,19}$

\section{CD1d Loading and Covalent Cross-Linking.}

Glyco-lipids dissolved in DMSO at $1 \mathrm{mg} / \mathrm{mL}$ were diluted to $100 \mu \mathrm{M}$ concentration in appropriate volumes of PBS and PBS plus $0.1 \%$ Triton X-100 to yield final DMSO concentration of $8-10 \%$ and $0.05 \%$ Triton X-100. Glycolipids were added to CD1d at a molar ratio of 3:1 in PBS plus $0.05 \%$ Triton X-100 (for in vitro applications) or PBS $+0.05 \%$ Tween-20 (for in vivo applications), and incubated for $12-18 \mathrm{~h}$ for complete loading of the complexes. Loaded complexes were transferred to ultralow binding microtiter plate wells and cooled on ice. A fixed wavelength UV lamp (Schleicher \& Schuell, RADFREE long wave UV lamp, $\lambda=365 \mathrm{~nm}$ ) was placed directly over wells containing complexes for $1 \mathrm{~h}$ on ice. Resulting conjugates were recovered from the wells and excess glycolipid and detergent was removed using detergent-removal columns (Pierce).

An azide-functionalized $\mathbf{1 3}$ was employed to determine the efficiency of covalent crosslinking. The azido-13 conjugates and complexes were covalently coupled to dibenzenecyclooctyne tetramethylrhodamine (DBCO-TAMRA, Click Chemistry Tools) by Huisgen cycloaddition. ${ }^{17}$ The ternary complex thus obtained was denatured using DTT and SDS and run on SDS-PAGE for detection. To determine stability of conjugates, the complexes and conjugates were coated onto high binding 96 well plates and washed with PBS-Tx-100 $0.05 \%$ every $12 \mathrm{~h}$ for 3 days to remove reversibly bound glycolipids. Plates were incubated at room temperature between washes.

For detection of mCD1d-glycolipid complexes and conjugates on glycolipid pulsed JAWS II cells, the cells were plated at $5 \times 10^{4}$ cells per well in microtiter plates and cultured with 100 $\mathrm{nM}$ of either $a$-GC C26:0 or $\mathbf{1 3}$ for $18 \mathrm{~h}$, followed by one wash with medium and then UV irradiation if indicated for $30 \mathrm{~min}\left(\sim 400 \mathrm{~mJ} / \mathrm{cm}^{2}\right)$. Samples of UV exposed and nonexposed cells were stained with mAb L363 coupled with AlexaFluor 647 and analyzed by flow cytometry using an LSR II flow cytometer (BD Biosciences) to determine surface bound glycolipid-CD1d complexes or conjugates (solid black bars), before and after incubation for 2 days to allow dissociation of glycolipids.

\section{In vitro and in vivo iNKT-Cell Stimulation Assays.}

To determine the $\mathrm{EC}_{50}$ of BPGCs, BMDCs from C57BL/6 mice or human CD1d transfected HeLa cells (HeLa.hCD1d) were cultured in microtiter plate wells $\left(5 \times 10^{4}\right.$ BMDC and $1 \times$ $10^{4} \mathrm{HeLa} . \mathrm{hCD} 1 \mathrm{~d}$ per well), and pulsed with varying BPGC concentrations ranging between $50 \mu \mathrm{M}$ and $0.01 \mathrm{nM}$ in $100 \mu \mathrm{L}$ of culture medium per well for $3 \mathrm{~h}$ at $37^{\circ} \mathrm{C}$. Cells were washed once to remove unbound glycolipid. The iNKT hybridoma DN3A4-1.2 or human iNKT clone HDE3 were then added ( $5 \times 10^{4}$ cells per well in $0.2 \mathrm{~mL}$ medium), and the cultures were maintained for $12-18 \mathrm{~h}$ at $37^{\circ} \mathrm{C}$. Stimulation was determined by measuring 
supernatant levels of IL-2 for DN3A4 1.2 or IFN- $\gamma$ for HDE3 by capture ELISA as described. ${ }^{30}$ Cytokine response was plotted against dose and $\mathrm{EC}_{50}$ was calculated using the function log agonist against response in Prism software.

To determine the serum cytokine levels induced in vivo in mice by administration of free glycolipids, glycolipid-loaded mCD1d complexes and conjugates, or ex vivo glycolipid loaded JAWS II cells, mice were bled at 2, 10, and $24 \mathrm{~h}$ following i.v. injections and serum samples were prepared. For free glycolipids, mice (3-5 per group) received $4 \mathrm{nmol}$ of $a$-GC $\mathrm{C} 26: 0,9,13$, or 15. For comparison of in vivo activity of conjugates, complexes, and free glycolipids, $30 \mu \mathrm{g} / \mathrm{mouse}$ of complexes or conjugates or equimolar amounts of free BPGCs ( 0.4 nanomoles) were injected into mice i.v. Serum cytokine levels were measured by capture ELISA.

\section{Mass Spectrometry and Proteomic Analyses.}

Tryptic and chymotryptic peptide digest mixtures of native mCD1d or conjugates were analyzed either directly by online nanoliquid chromatography (nano-LC) electrospray (ES) MS and MS/MS, or subjected to $N$-linked glycan release by PNGase F followed by subdigestion with additional proteases prior to analysis. For detailed methods, see SI Methods section.

\section{Computational Molecular Modeling and Docking Studies.}

Binding modes of $\mathbf{9}$ and $\mathbf{1 3}$ glycolipids to mCD1d were predicted using the mCD1d/ $a$ GC/TCR crystal structure with PDB entry code 3HE6, containing Va14-V $\beta 8.2$ iNKT TCR (mouse variable, human constant domains). The crystal structure was prepared using Protein Preparation Wizard tools (Schrödinger software package, version 2016-1). For detailed methods, see SI Methods section.

\section{Statistical Analysis.}

Results are expressed as mean \pm SEM. Statistical significance between the groups was determined with multiple $t$ tests, one-way-ANOVA or two-way-ANOVA tests with the Bonferroni correction as indicated. All statistical analyses were done using GraphPad Prism software.

\section{Supplementary Material}

Refer to Web version on PubMed Central for supplementary material.

\section{ACKNOWLEDGMENTS}

Major funding support was provided by NIH/NIAID grant R01 AI45889 and U01 GM111849 (to S.A.P.). G.S.B. acknowledges support in the form of a Personal Research Chair from Mr. James Bardrick and a Royal Society Wolfson Research Merit Award. S.M.H and S.J.N. were supported by Biotechnology and Biological Sciences Research Council Grant BB/K016164/1. Flow cytometry and recombinant protein production were supported by core facilities of the Albert Einstein College of Medicine Cancer Center (NCI grant CA13330). We thank Drs. Alena Donda (Ludwig Cancer Institute) and Amy Howell (University of Connecticut) for helpful discussions. 


\section{REFERENCES}

(1). Brennan PJ, Brigl M, and Brenner MB (2013) Invariant natural killer T cells: an innate activation scheme linked to diverse effector functions. Nat. Rev. Immunol 13 (2), 101-17. [PubMed: 23334244]

(2). Rossjohn J, Pellicci DG, Patel O, Gapin L, and Godfrey DI (2012) Recognition of CD1d-restricted antigens by natural killer T cells. Nat. Rev. Immunol 12 (12), 845-57. [PubMed: 23154222]

(3). Laurent X, Bertin B, Renault N, Farce A, Speca S, Milhomme O, Millet R, Desreumaux P, Henon E, and Chavatte P (2014) Switching invariant natural killer T (iNKT) cell response from anticancerous to anti-inflammatory effect: molecular bases. J. Med. Chem 57 (13), 5489-508. [PubMed: 24428717]

(4). (a)Kawano T, Cui J, Koezuka Y, Toura I, Kaneko Y, Motoki K, Ueno H, Nakagawa R, Sato H, Kondo E, et al. (1997) CD1d-restricted and TCR-mediated activation of valpha14 NKT cells by glycosylceramides. Science 278 (5343), 1626-9. [PubMed: 9374463] (b)Motoki K, Morita M, Kobayashi E, Uchida T, Akimoto K, Fukushima H, and Koezuka Y (1995) Immunostimulatory and antitumor activities of monoglycosylceramides having various sugar moieties. Biol. Pharm. Bull 18 (11), 1487-91. [PubMed: 8593464] (c)Nair S, and Dhodapkar MV (2017) Natural Killer T Cells in Cancer Immunotherapy. Front. Immunol 8, 1178. [PubMed: 29018445]

(5). (a)Cerundolo V, and Salio M (2007) Harnessing NKT cells for therapeutic applications. Curr. Top Microbiol Immunol 314, 325-40. [PubMed: 17593667] (b)Cerundolo V, Silk JD, Masri SH, and Salio M (2009) Harnessing invariant NKT cells in vaccination strategies. Nat. Rev. Immunol 9 (1), 28-38. [PubMed: 19079136]

(6). (a)Kharkwal SS, Arora P, and Porcelli SA (2016) Glycolipid activators of invariant NKT cells as vaccine adjuvants. Immunogenetics 68 (8), 597-610. [PubMed: 27377623] (b)Exley MA, and Nakayama T (2011) NKT-cell-based immunotherapies in clinical trials. Clin. Immunol 140 (2), 117-8. [PubMed: 21592864]

(7). (a)Birkholz AM, and Kronenberg M (2015) Antigen specificity of invariant natural killer T-cells. Biomed J. 38 (6), 470-83. [PubMed: 27013447] (b)Carreno LJ, Saavedra-Avila NA, and Porcelli SA (2016) Synthetic glycolipid activators of natural killer T cells as immunotherapeutic agents. Clin. Transl. Immunol 5 (4), e69.

(8). (a)Fujii S, Shimizu K, Kronenberg M, and Steinman RM (2002) Prolonged IFN-gamma-producing NKT response induced with alpha-galactosylceramide-loaded DCs. Nat. Immunol 3 (9), 867-74. [PubMed: 12154358] (b)Kimura H, Matsui Y, Ishikawa A, Nakajima T, Yoshino M, and Sakairi Y (2015) Randomized controlled phase III trial of adjuvant chemo-immunotherapy with activated killer T cells and dendritic cells in patients with resected primary lung cancer. Cancer Immunol. Immunother 64 (1), 51-9. [PubMed: 25262164] (c)Stirnemann K, Romero JF, Baldi L, Robert B, Cesson V, Besra GS, Zauderer M, Wurm F, Corradin G, Mach JP, et al. (2008) Sustained activation and tumor targeting of NKT cells using a CD1d-anti-HER2-scFv fusion protein induce antitumor effects in mice. J. Clin. Invest 118 (3), 994-1005. [PubMed: 18259610] (d)Corgnac S, Perret R, Derre L, Zhang L, Stirnemann K, Zauderer M, Speiser DE, Mach JP, Romero P, and Donda A (2013) CD1d-antibody fusion proteins target iNKT cells to the tumor and trigger longterm therapeutic responses. Cancer Immunol. Immunother 62 (4), 747-60. [PubMed: 23242316]

(9). Wolf BJ, Choi JE, and Exley MA (2018) Novel Approaches to Exploiting Invariant NKT Cells in Cancer Immunotherapy. Front. Immunol 9, 384. [PubMed: 29559971]

(10). Parekh VV, Wilson MT, Olivares-Villagomez D, Singh AK, Wu L, Wang CR, Joyce S, and Van Kaer L (2005) Glycolipid antigen induces long-term natural killer T cell anergy in mice. J. Clin. Invest 115 (9), 2572-83. [PubMed: 16138194]

(11). (a)Naidenko OV, Maher JK, Ernst WA, Sakai T, Modlin RL, and Kronenberg M (1999) Binding and antigen presentation of ceramide-containing glycolipids by soluble mouse and human CD1d molecules. J. Exp. Med 190 (8), 1069-80. [PubMed: 10523605] (b)Sidobre S, Hammond KJ, Benazet-Sidobre L, Maltsev SD, Richardson SK, Ndonye RM, Howell AR, Sakai T, Besra GS, Porcelli SA, et al. (2004) The T cell antigen receptor expressed by Valpha14i NKT cells has a unique mode of glycosphingolipid antigen recognition. Proc. Natl. Acad. Sci. U. S. A 101 (33), 12254-9. [PubMed: 15304644] (c)van den Elzen P, Garg S, Leon L, Brigl M, Leadbetter EA, Gumperz JE, Dascher CC, Cheng TY, Sacks FM, Illarionov PA, et al. (2005) Apolipoprotein- 
mediated pathways of lipid antigen presentation. Nature 437 (7060), 906-10. [PubMed: 16208376] (d)Yuan W, Qi X, Tsang P, Kang SJ, Illarionov PA, Besra GS, Gumperz J, and Cresswell P (2007) Saposin B is the dominant saposin that facilitates lipid binding to human CD1d molecules. Proc. Natl. Acad. Sci. U. S. A 104 (13), 5551-6. [PubMed: 17372201]

(12). (a)Gao B, Radaeva S, and Park O (2009) Liver natural killer and natural killer T cells: immunobiology and emerging roles in liver diseases. J. Leukocyte Biol 86 (3), 513-28. [PubMed: 19542050] (b)Szabo PA, Rudak PT, Choi J, Xu SX, Schaub R, Singh B, McCormick JK, and Haeryfar SMM (2016) Invariant Natural Killer T Cells Are Pathogenic in the HLA-DR4Transgenic Humanized Mouse Model of Toxic Shock Syndrome and Can Be Targeted to Reduce Morbidity. J. Infect. Dis 215 (5), 824-829.

(13). (a)Koch M, Stronge VS, Shepherd D, Gadola SD, Mathew B, Ritter G, Fersht AR, Besra GS, Schmidt RR, Jones EY, et al. (2005) The crystal structure of human CD1d with and without alpha-galactosylceramide. Nat. Immunol 6 (8), 819-26. [PubMed: 16007090] (b)Zeng Z, Castano AR, Segelke BW, Stura EA, Peterson PA, and Wilson IA (1997) Crystal structure of mouse CD1: An MHC-like fold with a large hydrophobic binding groove. Science 277 (5324), 339-45. [PubMed: 9219685]

(14). Mitchell D, Lukeman M, Lehnherr D, and Wan P (2005) Formal intramolecular photoredox chemistry of meta-substituted benzophenones. Org. Lett 7 (15), 3387-9. [PubMed: 16018667]

(15). Im JS, Arora P, Bricard G, Molano A, Venkataswamy MM, Baine I, Jerud ES, Goldberg MF, Baena A, Yu KO, et al. (2009) Kinetics and cellular site of glycolipid loading control the outcome of natural killer T cell activation. Immunity 30 (6), 888-98. [PubMed: 19538930]

(16). Bricard G, Venkataswamy MM, Yu KO, Im JS, Ndonye RM, Howell AR, Veerapen N, Illarionov PA, Besra GS, Li Q, et al. (2010) Alpha-galactosylceramide analogs with weak agonist activity for human iNKT cells define new candidate anti-inflammatory agents. PLoS One 5 (12), e14374. [PubMed: 21179412]

(17). Jeon J, Kang JA, Shim HE, Nam YR, Yoon S, Kim HR, Lee DE, and Park SH (2015) Efficient method for iodine radioisotope labeling of cyclooctyne-containing molecules using strainpromoted copper-free click reaction. Bioorg. Med. Chem 23 (13), 3303-8. [PubMed: 25960325]

(18). Yu KO, Im JS, Illarionov PA, Ndonye RM, Howell AR, Besra GS, and Porcelli SA (2007) Production and characterization of monoclonal antibodies against complexes of the NKT cell ligand alpha-galactosylceramide bound to mouse CD1d. J. Immunol. Methods 323 (1), 11-23. [PubMed: 17442335]

(19). Arora P, Baena A, Yu KO, Saini NK, Kharkwal SS, Goldberg MF, Kunnath-Velayudhan S, Carreno LJ, Venkataswamy MM, Kim J, et al. (2014) A single subset of dendritic cells controls the cytokine bias of natural killer $\mathrm{T}$ cell responses to diverse glycolipid antigens. Immunity 40 (1), 105-16. [PubMed: 24412610]

(20). (a)Thakur MS, Khurana A, Kronenberg M, and Howell AR (2014) Synthesis of a 2"-deoxy-betaGalCer. Molecules 19 (7), 10090-102. [PubMed: 25014535] (b)Arora P, Kharkwal SS, Ng TW, Kunnath-Velayudhan S, Saini NK, Johndrow CT, Chang YT, Besra GS, and Porcelli SA (2015) Endocytic $\mathrm{pH}$ regulates cell surface localization of glycolipid antigen loaded CD1d complexes. Chem. Phys. Lipids 191, 75-83. [PubMed: 26306469] (c)Huang JR, Tsai YC, Chang YJ, Wu JC, Hung JT, Lin KH, Wong CH, and Yu AL (2014) alpha-Galactosylceramide but not phenylglycolipids induced NKT cell anergy and IL-33-mediated myeloid-derived suppressor cell accumulation via upregulation of egr2/3. J. Immunol 192 (4), 1972-81. [PubMed: 24465013]

(21). Wingender G, Birkholz AM, Sag D, Farber E, Chitale S, Howell AR, and Kronenberg M (2015) Selective Conditions Are Required for the Induction of Invariant NKT Cell Hyporesponsive-ness by Antigenic Stimulation. J. Immunol 195 (8), 3838-48. [PubMed: 26355152]

(22). Giaccone G, Punt CJ, Ando Y, Ruijter R, Nishi N, Peters M, von Blomberg BM, Scheper RJ, van der Vliet HJ, van den Eertwegh AJ, et al. (2002) A phase I study of the natural killer T- cell ligand alpha-galactosylceramide (KRN7000) in patients with solid tumors. Clin. Cancer Res 8 (12), 3702-9. [PubMed: 12473579]

(23). (a)Ishikawa A, Motohashi S, Ishikawa E, Fuchida H, Higashino K, Otsuji M, Iizasa T, Nakayama T, Taniguchi M, and Fujisawa T (2005) A phase I study of alpha-galactosylceramide (KRN7000)-pulsed dendritic cells in patients with advanced and recurrent non-small cell lung cancer. Clin. Cancer Res 11 (5), 1910-7. [PubMed: 15756017] (b)Kunii N, Horiguchi S, 
Motohashi S, Yamamoto H, Ueno N, Yamamoto S, Sakurai D, Taniguchi M, Nakayama T, and Okamoto Y (2009) Combination therapy of in vitro-expanded natural killer T cells and alphagalactosylceramide-pulsed antigen-presenting cells in patients with recurrent head and neck carcinoma. Cancer Sci. 100 (6), 1092-8. [PubMed: 19302288]

(24). (a)Schmieg J, Yang G, Franck RW, and Tsuji M (2003) Superior protection against malaria and melanoma metastases by a C-glycoside analogue of the natural killer T cell ligand [alpha]galactosylceramide. J. Exp. Med 198, 1631-1641. [PubMed: 14657217] (b)Aspeslagh S, Nemcovic M, Pauwels N, Venken K, Wang J, Van Calenbergh S, Zajonc DM, and Elewaut D (2013) Enhanced TCR footprint by a novel glycolipid increases NKT-dependent tumor protection. J. Immunol 191 (6), 2916-25. [PubMed: 23960235]

(25). Girardi E, Yu ED, Li Y, Tarumoto N, Pei B, Wang J, Illarionov P, Kinjo Y, Kronenberg M, and Zajonc DM (2011) Unique interplay between sugar and lipid in determining the antigenic potency of bacterial antigens for NKT cells. PLoS Biol. 9 (11), e1001189. [PubMed: 22069376]

(26). Exley M, Garcia J, Balk SP, and Porcelli S (1997) Requirements for CD1d recognition by human invariant Valpha24+ CD4-CD8-T cells. J. Exp. Med 186 (1), 109-20. [PubMed: 9207002]

(27). Khurana A, and Kronenberg M (2007) A method for production of recombinant mCD1d protein in insect cells. J. Visualized Exp 10, 556.

(28). Im JS, Yu KO, Illarionov PA, LeClair KP, Storey JR, Kennedy MW, Besra GS, and Porcelli SA (2004) Direct measurement of antigen binding properties of CD1 proteins using fluorescent lipid probes. J. Biol. Chem 279 (1), 299-310. [PubMed: 14551186]

(29). Arora P, Venkataswamy MM, Baena A, Bricard G, Li Q, Veerapen N, Ndonye R, Park JJ, Lee JH, Seo KC, et al. (2011) A rapid fluorescence-based assay for classification of iNKT cell activating glycolipids. J. Am. Chem. Soc 133 (14), 5198-201. [PubMed: 21425779]

(30). Jervis PJ, Veerapen N, Bricard G, Cox LR, Porcelli SA, and Besra GS (2010) Synthesis and biological activity of alpha-glucosyl C24:0 and C20:2 ceramides. Bioorg. Med. Chem. Lett 20 (12), 3475-8. [PubMed: 20529677] 
a

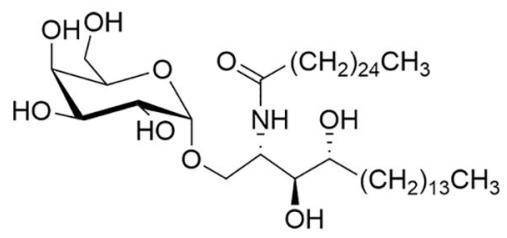

b<smiles>O=C(c1ccccc1)c1cccc(CBr)c1</smiles>

(a)<smiles>CC(C)(CO)C(C)(C)CO</smiles><smiles>CC(CO)COCc1cccc(C(=O)c2ccccc2)c1</smiles><smiles>O=C(O)CCCOCc1cccc(C(=O)c2ccccc2)c1</smiles>

$2(n=4), 3(n=7), 4(n=8), 5(n=14)$ (c)<smiles>O=C(c1ccccc1)c1cccc(CO)c1</smiles>

(d)<smiles>CC(CBr)(CBr)C(=O)O</smiles><smiles>O=C(O)CCCOCc1cccc(C(=O)c2ccccc2)c1</smiles>

$6(n=6), 7(n=9), 8(n=10)$<smiles>CC1CC1C</smiles>

(e) $(\mathrm{COCl})_{2}$

(f)<smiles>OCC1OCC(O)C(O)C(O)C1O</smiles><smiles>CCCCCC(N)C(O)C(O)CC</smiles>

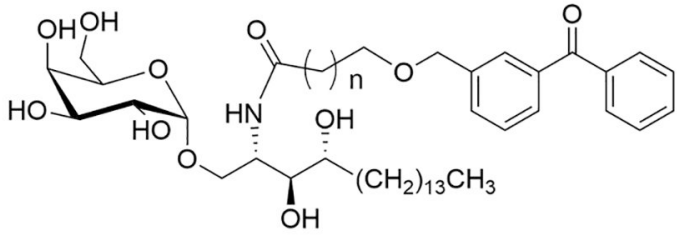

9, C6:BP (n=4); 10, C8:BP (n=6); 11, C9:BP $(n=7) ; 12, C 10: B P(n=8)$; 13, C11:BP ( $n=9) ; 14, C 12: B P(n=10) ; 15, C 16: B P(n=14)$

Figure 1.

Synthesis of BPGCs. (a) Structure of the prototypical iNKT cell activating glycolipid, $a$-GC C26:0. (b) General scheme for synthesis of BPGCs with acyl group spacers of varying length (compounds 9-15): (a) $\mathrm{NaH}, \mathrm{DMF}, 0^{\circ} \mathrm{C}$ to rt; (b) $\mathrm{PDC}$, wet THF, rt; (c) $\mathrm{CaCO}_{3}$, THF, $\mathrm{H}_{2} \mathrm{O}, 100{ }^{\circ} \mathrm{C}, 12 \mathrm{~h}$; (d) $\mathrm{NaH}, \mathrm{DMF}, 0{ }^{\circ} \mathrm{C}$ to rt; (e) $(\mathrm{COCl})_{2}, 60{ }^{\circ} \mathrm{C}, 2 \mathrm{~h}$; (f) $\mathrm{NaOAc}$, THF, rt, $12 \mathrm{~h}$. Incorporation of the benzophenone group into carboxylic acids was accomplished through the use of a flexible ether linkage to allow rotational freedom and optimal orientation of the aromatic group in the CD1d ligand-binding pocket. To synthesize carboxylic acids (2-8), we used a versatile strategy involving an $\mathrm{S}_{\mathrm{N}} 2$ displacement of a bromide using various diols and 3-(bromomethyl)benzophenone (16) or through a variety of bromocarboxylic acids by 3-(hydroxymethyl)-benzophenone (17). The monoalkylation of the diols with 3-(bromomethyl)benzophenone (16), which was obtained using published procedures, ${ }^{14}$ was achieved in reasonable yields by using the diols in excess. Oxidation of 
the corresponding alcohols to the acids with pyridinium dichromate (PDC) was sluggish and only afforded compounds $\mathbf{2 - 5}$ in average yields. In contrast, alkylation of the alcohol 17 with the bromocarboxylic acids in DMF and sodium hydride as base proceeded smoothly to afford the desired carboxylic acids 6-8 in quantitative yields (see Supporting Information for further details of synthesis and characterization). 
a

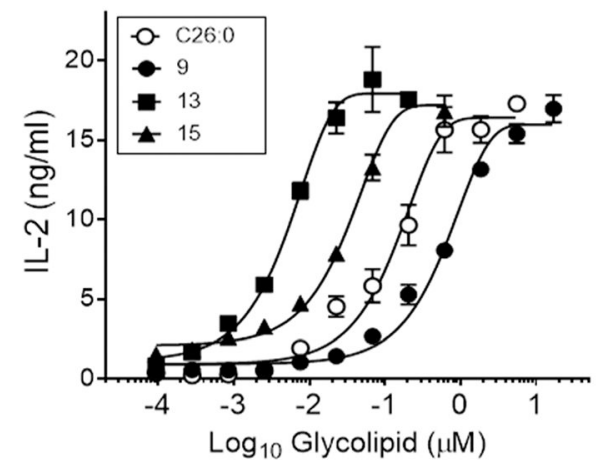

b

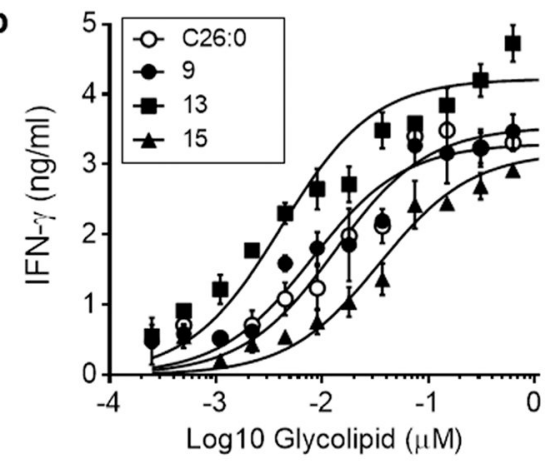

mouse CD1d

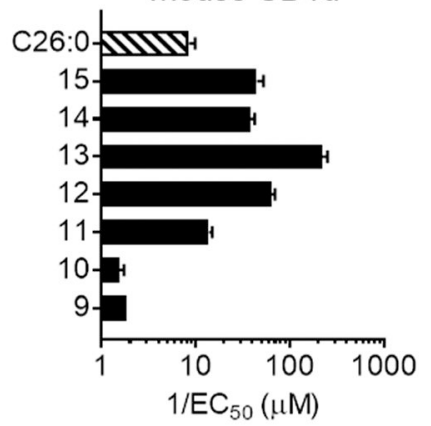

human CD1d

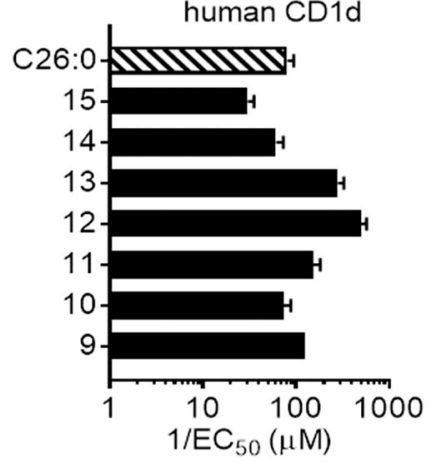

c

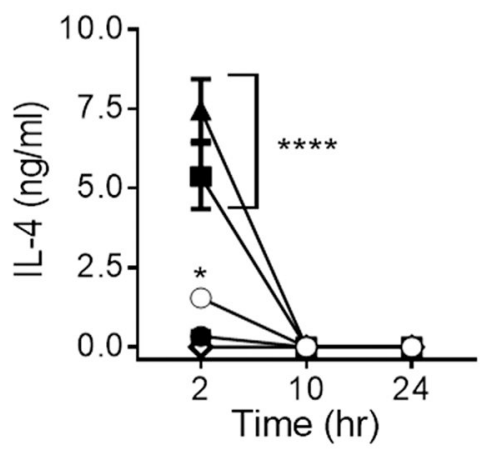

Figure 2.

iNKT stimulatory activity of BPGCs. (a) Responses of mouse iNKT cell hybridoma DN3A4-1.2 cultured with bone marrow derived dendritic cells from C57BL/6 mice and the indicated concentrations of BPGCs or $a$-GC C26:0. IL-2 secretion was measured in supernatants after $18 \mathrm{~h}$ of culture. Representative dose-response curves are shown on the left for three of the seven BPGCs and standard $a$-GC C26:0. Concentrations stimulating 50\% of the maximum response $\left(\mathrm{EC}_{50}\right)$ were determined for each glycolipid, and reciprocal values are plotted on the right. (b) Similar analysis to (a) except using human iNKT clone HDE3 and HeLa cells expressing human CD1d with measurement of secreted IFN $\gamma$ as the readout for activation. (c) In vivo activities of $9, \mathbf{1 3}$, and 15 were determined by quantitating serum IL-4 and IFN- $\gamma 2,10$, and $24 \mathrm{~h}$ post glycolipid injection. Peak values for serum IL4 (left) and IFN- $\gamma$ (right) were found at 2 and $10 \mathrm{~h}$, respectively. All symbols and bars are means for triplicate samples, and error bars are $\pm 1 \mathrm{SD} * P<0.05$, $* * P<0.01, * * * P<0.001$, and $* * * * P$ 
$<0.0001$ for comparisons to vehicle treated mice (two-way ANOVA with Dunnett's multiple comparison test). All data are representative of at least three separate experiments. 


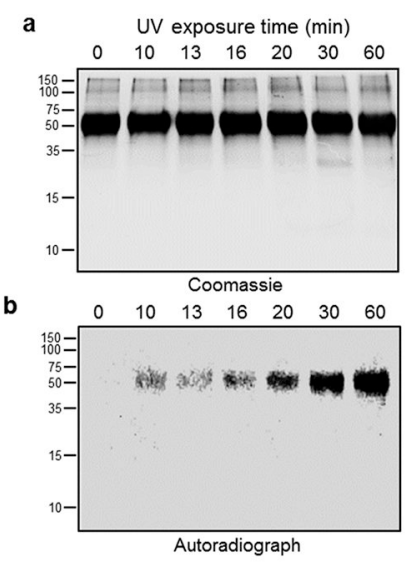

c

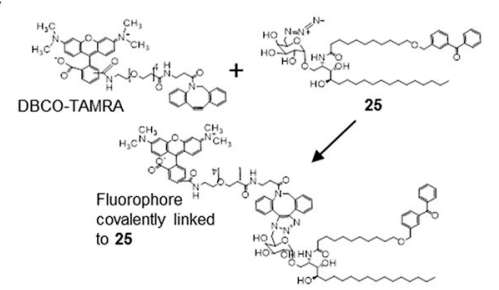

d
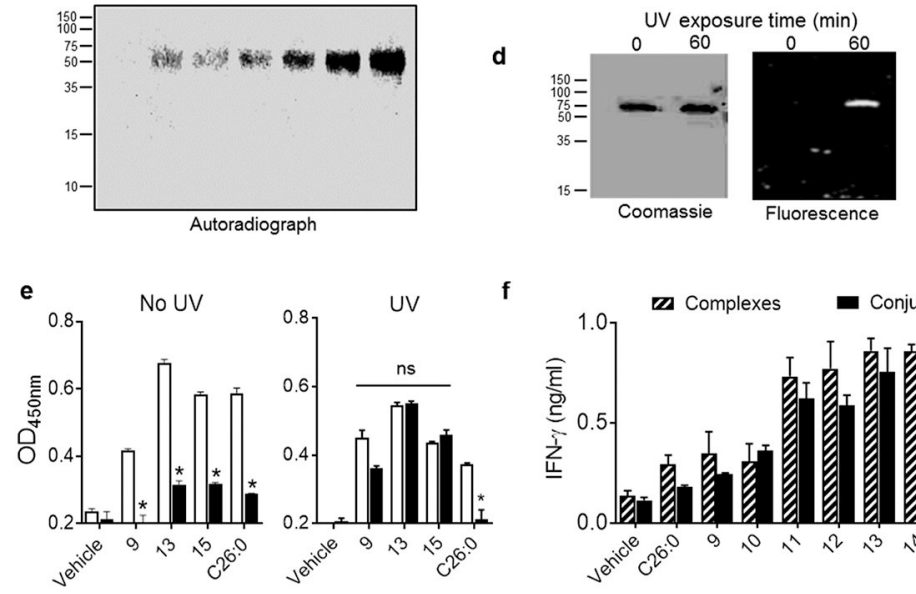

f
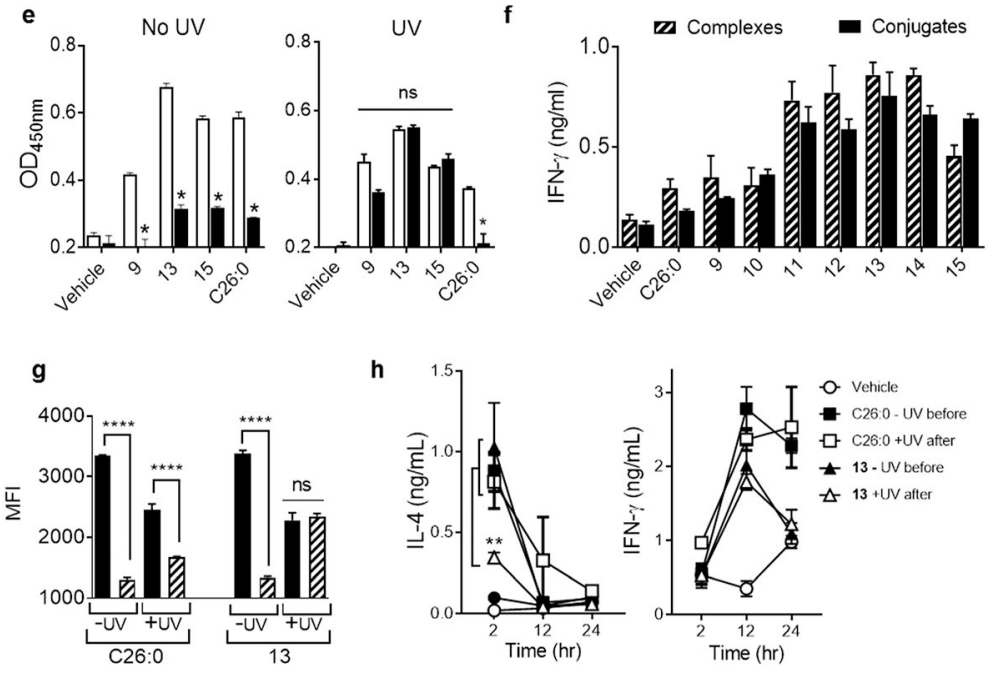

Figure 3.

Covalent conjugation of BPGCs to mCD1d. (a) Coomassie stained gel and (b) autoradiograph of denaturing SDS-PAGE after exposing mCD1d: ${ }^{14} \mathrm{C}$-labeled analogue of 13, compound 26 (Scheme 2, SI) complexes ( $\sim 57 \mathrm{kDa}$ ) for various lengths of time. (c) Diagrammatic representation of click reaction of DBCO-TAMRA dye with azide-linked-25 (SI) either loaded noncovalently or covalently conjugated to CD1d protein. (d) Coomassie stained and fluorescent images of denaturing SDS-PAGE gel of fluorescently tagged noncovalent complexes ( 0 min UV exposure) and covalent conjugates (60 min UV exposure) of mCD1d fusion protein ( 78 kDa). (e) Complexes (No UV, left) or conjugates (UV, right) loaded with the indicated BPGC or $a$-GC-C26:0 were coated on high binding plates and incubated for 3 days at room temperature either without (white bars) or with (black bars) washing twice per day with PBS $+0.1 \%$ Triton X-100. Residual glycolipid binding to mCD1d was detected by ELISA using biotinylated monoclonal antibody L363. $* P<0.001$ for multiple $t$ tests of comparisons of washed versus unwashed samples with each glycolipid. (f) Splenocytes $\left(2 \times 10^{5}\right.$ per well in $0.2 \mathrm{~mL}$ complete medium) were stimulated in vitro for $18 \mathrm{~h}$ with complexes (hatched bars) and conjugates (solid bars) immobilized on high binding plates. Supernatants were collected and assayed for IFN- $\gamma$ by ELISA. (g) JAWS II cells $(5 \times$ $10^{4}$ per well) pulsed overnight with $100 \mathrm{nM}$ glycolipids (C26:0 or 13) were either exposed 
to UV $\left(\sim 400 \mathrm{~mJ} / \mathrm{cm}^{2}\right)$ or left untreated. Cells were stained with L363-AlexaFluor647 either directly (solid black bars) or after multiple washes (hatched bars) to allow dissociation and analyzed by flow cytometry. $* * * * P<0.0001$, two-way ANOVA with Bonferroni correction for indicated comparisons. (h) JAWS II cells were exposed to UV $\left(600 \mathrm{~mJ} / \mathrm{cm}^{2}\right)$ either before (black symbols) or after (white symbols) pulsing with vehicle, C26:0 or 13 at $100 \mathrm{nM}$ concentration. Cells were washed thrice during $24 \mathrm{~h}$ of incubation and adoptively transferred i.v. into mice $\left(3 \times 10^{5}\right.$ cells per mouse, 4 mice per group). Blood samples were obtained after 2,12 , and $24 \mathrm{~h}$ to quantitate serum IL-4 and IFN- $\gamma$. $* * P<0.01$, two-way ANOVA with Bonferroni correction for indicated comparisons. Data plotted in (e,f) are shown as means for a minimum of three replicates, and error bars are $\pm 1 \mathrm{SD}$. All experiments were performed at least three times. 
a

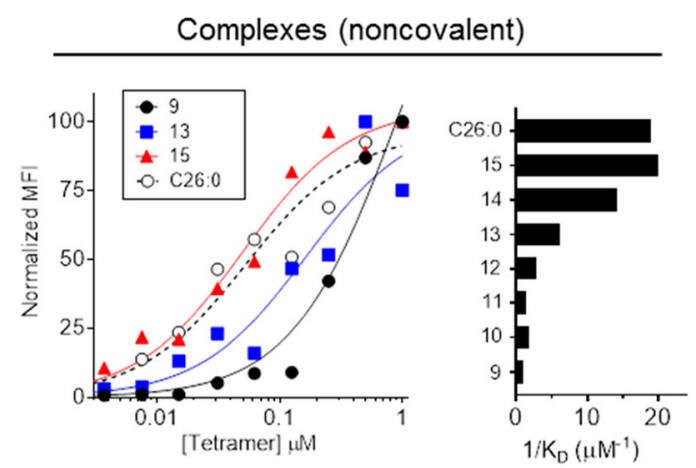

Conjugates (covalent)
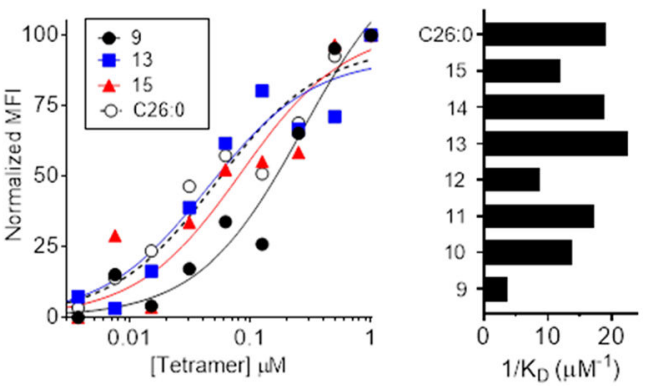

10 hours

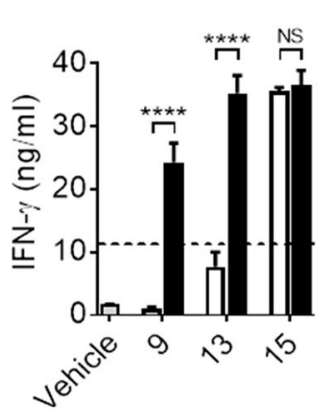

Figure 4.

Affinity for iNKT cell TCR and effects on cytokine profiles. (a) Equilibrium binding of mCD1d tetramers loaded with BPGCs over a range of tetramer concentrations was used to assess avidities of complexes (not UV irradiated, left) and conjugates (UV irradiated, right) for TCRs of mouse iNKT cell hybridoma DN3A4-1.2. Cells stained with tetramers for $1 \mathrm{~h}$ at room temperature were analyzed by flow cytometry. Normalized representative binding curves are shown for three BPGC loaded tetramers, and for standard C26:0 loaded tetramers (not UV irradiated) for comparison (dashed lines). Bar graphs show reciprocal of $K_{\mathrm{D}}$ values $\left(1 / \mathrm{EC}_{50}\right)$ to summarize results for all tetramers. (b) Serum cytokine levels following i.v. injection of mice with complexes (open bars) or conjugates (filled bars) loaded with the indicated BPGCs. Serum levels are shown at $2 \mathrm{~h}$ post-injection for IL-2, TNF- $a$, and IL-4, and at $10 \mathrm{~h}$ for IFN- $\gamma$. Background levels of cytokines in sera from mice injected with inert aqueous vehicle (gray bars), and levels for mice injected with $4 \mathrm{nmol}$ of free C26:0 glycolipid (horizontal dashed lines) are shown for reference. Bars represent means for groups of 4 animals each, and error bars show $1 \mathrm{SD} * * * * P<0.0001$ for conjugate versus complex in the indicated comparisons (2-way ANOVA with Bonferroni's multiple comparisons test). NS, not significant $(P>0.05)$. Differences were not significant for other comparisons shown between complexes and conjugates. 
a

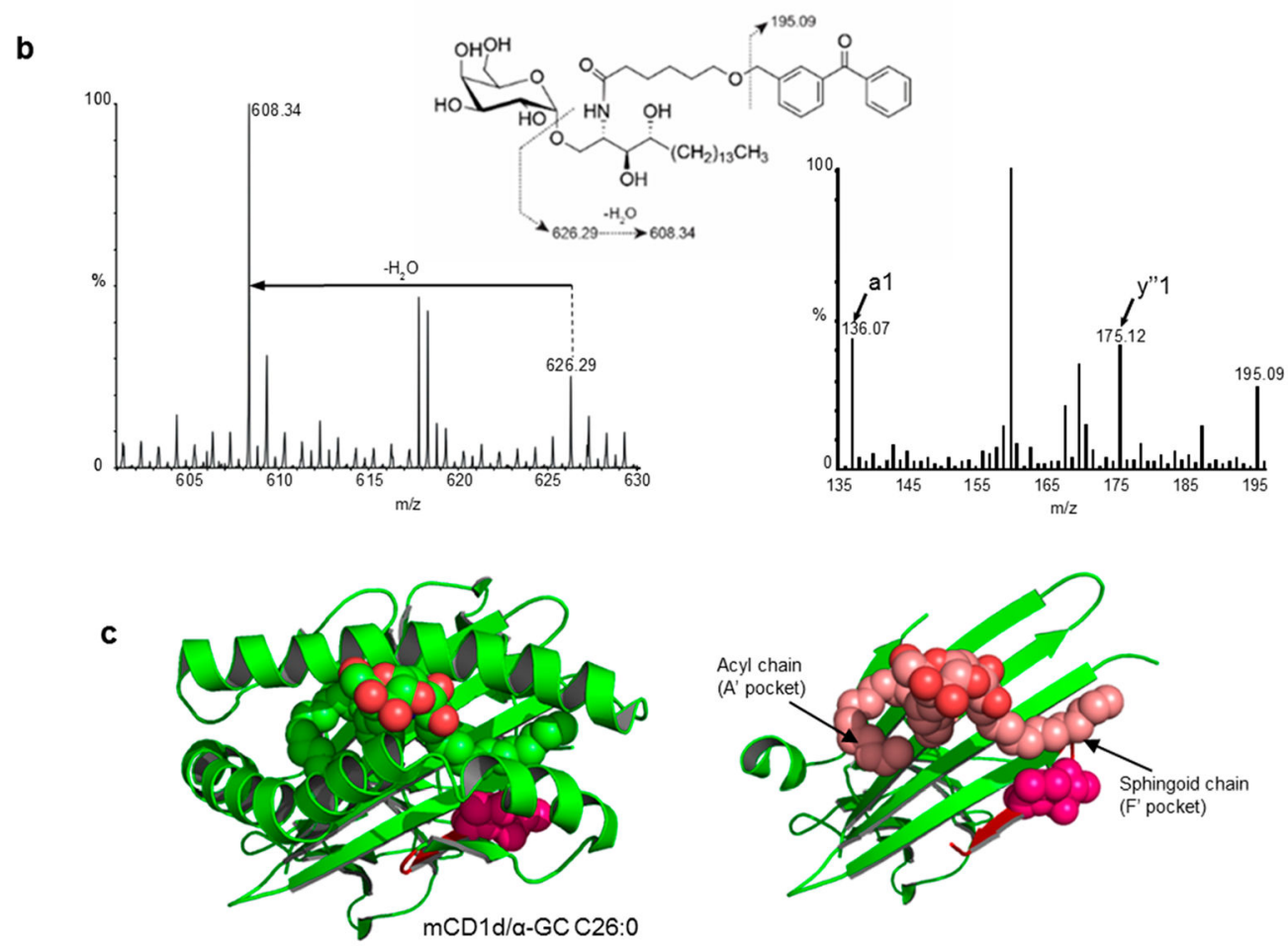

9- Conjugate

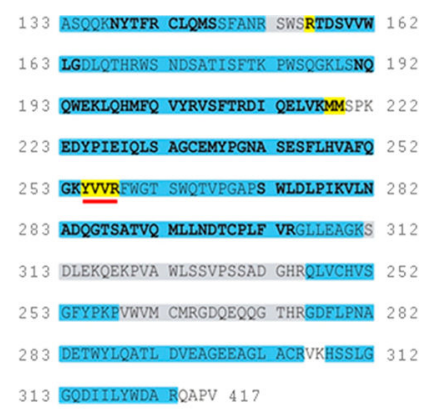

13- Conjugate

133 ASQQWNYTER CLOMSSEANB SWSRTDSWWW 162

163 LGDLOTHRWS NDSATISETK PNSOGRLSNQ 192

193 QWEKLQRMEQ VXRVSFTRDI QSIVKMMSPK 222

223 EDYPIEIQLS AGCEMYPGNA SESELHVAFQ 252

253 GKYVVREMGT SMOTVPGAPS WLDIPIKULN 282

33 ADQGTSATVQ MLINDTCPLF VBGLLEAGKS 312

13 DLEKREKRVA WLSSVPSSAD GHRQLVCHVS 252

253 GEYPRPVWVM CMRGDQEQQG THRGDELPNA 282

283 DETWYLQATL DVEAGEEAGL ACRVKHSSLG 312

313 GODIILYWDA BQAPV 417

Figure 5.

Mapping of covalent attachment site. (a) Peptide mapping summaries from nano-LC-ES$\mathrm{MS}^{\mathrm{E}}$ analyses are shown for unloaded $\mathrm{mCD} 1 \mathrm{~d}$ fusion protein (native) and for protein -glycolipid conjugates containing either 9 or $\mathbf{1 3}$, focusing on the lipid binding region comprising the $a 1$ and $a 2$ regions of CD1d. Amino acid sequences of mCD1d $a 1$ through $a 2$ domains are shown in single letter code. Bold text indicates residues forming the lipid binding pocket, blue shading indicates residues mapped with a high degree of confidence, and gray shading indicates residues mapped with a good degree of confidence. Residues highlighted in yellow indicate amino acids that were not observed in any detected peptides. Peptides containing the four amino acids underlined in red in both conjugates were detected with high confidence in the native protein but, were absent in both conjugates. (b) $\mathrm{MS}^{\mathrm{E}}$ analysis of the doubly charged ion $\mathrm{m} / z 661.33$ observed at 30.9 min elution time in the analysis of a reduced, carbamidomethylated, PNGase-F treated tryptic digest of the 9 
conjugate. The molecular ion is consistent with the tryptic peptide containing the ${ }_{255} \mathrm{YVVR}_{258}$ residues modified by a single $\mathrm{C} 6$ glycolipid moiety. Labeled ions in the left panel show loss of water from a cleaved C6 BPGC entity, while the right panel highlights evidence for the peptide with the $\mathrm{y}^{\prime \prime} 1$ ion for the C-terminal arginine at $\mathrm{m} / z 175$ and the a1ion for the N-terminal tyrosine at $\mathrm{m} / z$ 136. The ion at $\mathrm{m} / z 195$ is consistent with loss of the benzophenyl group from the BPGC molecule. (c) The mCD1d protein structure previously deduced from X-ray crystallography (PDB number 3HE6) is shown as a ribbon diagram in green, and the two valine residues comprising the proposed covalent attachment site are shown as bright pink spheres. The view on the left shows the intact $a 1$ and $a 2$ domains with $a$-GC C26:0 (green and red spheres) bound in the lipid binding groove. In the view on the right, the $a$-helices forming the roof of the groove have been removed, and the bound glycolipid is shown as pink and red spheres. 


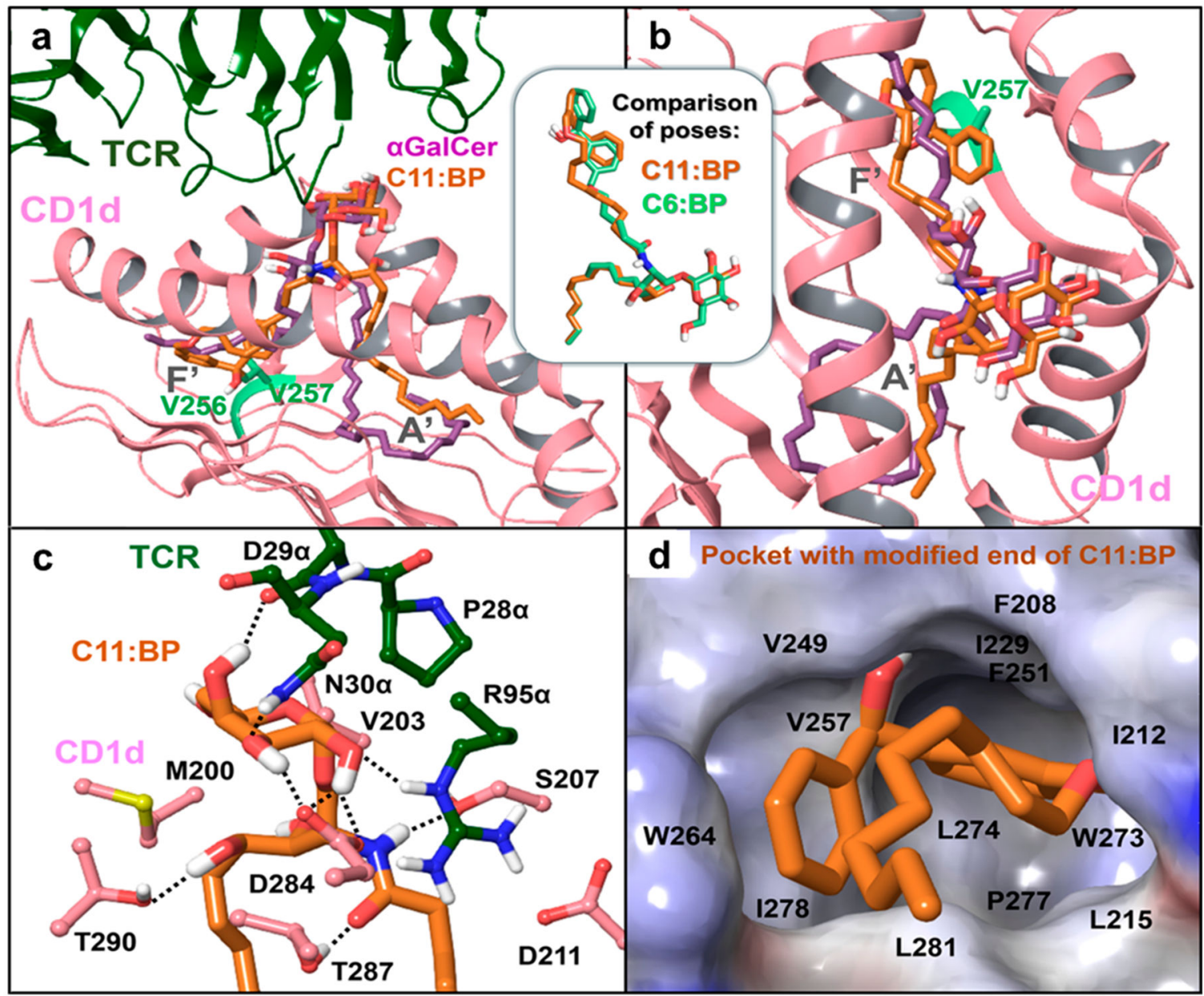

Figure 6.

Molecular docking of $\mathbf{1 3}$ and $\mathbf{9}$ in mCD1d. (a, b) Two views of the binding model of $\mathbf{1 3}$ and cocrystallized $a$-GC (from PDB code 3HE6). The inset compares the binding models of 13 (C11:BP) and 9 (C6:BP). The modified end in the $\mathrm{F}^{\prime}$ pocket is covalently attached to $\mathrm{V} 257$ (residue V125 in the structure with PDB code 3HE6). (c) Interactions near the sugar moiety of 13. A TCR interaction shared between $a$-GC C26:0 in the crystal structure and both 9 and 13 models was the hydrogen-bonding interaction of the galactose $3^{\prime \prime}-\mathrm{OH}$ with $\mathrm{N} 30 \mathrm{a}$. Additional stabilizing interactions with the sugar moiety of the bound BPGCs included hydrogen bonds with TCR residues R95 $a$ and D29 $a$ and with D284 of mCD1d. The binding site that in the crystal structure is occupied by the vicinal diol of the phytosphingosine chain of $a$-GC was occupied in the BPGC bound models by a less bulky amide group. This allowed reorientation of the TCR $a$ R95 side chain (R95a) into the same region, forming a favorable stacking interaction between the guanidinium of the arginine and the amide of the ligand. The guanidinium of R95 $a$ was also sandwiched between the mCD1d residues D284 and D211, salt-bridging with both aspartates. Other interactions stabilizing the predicted BPGC binding orientation were apparent, such as hydrogen bonds between the amide group and residues S207 and T287 of mCD1d, and between the C3 hydroxyl of the phytosphingosine chain and residue T290 of mCD1d. (d) CD1d surface in the region of the modified terminal, colored by electrostatic potential (blue indicates nonpolar and red 
indicates polar surfaces). The end group forms favorable nonpolar contacts with I229, V249, F251, W264, W273, L274, I278, and L281 (residue numbers are based on the mCD1dfusion protein). 